\title{
Implementasi Pembelajaran Bermakna Pada Mata Pelajaran Pendidikan Agama Kristen Dan Budi Pekerti Di Sekolah Menengah Atas
}

\author{
Aang Setiadi \\ Guru PAK Smtk Bethel Jakarta \\ aangsetiadi02@gmail.com
}

\begin{abstract}
The study of Christian education and ethics or later referred to as PAK in this journal, is a subject that must be followed by all learners who embrace Christianity. The education of Christianity and Ethics is a government-supported education, it can be seen in the 2013 curriculum unit. MR. And Budi ethics are expected to be a pioneer in character education and national values that each graduate can have to answer future challenges. Therefore, the high school, especially the teacher must be able to give the study of PAK that has meaning in the life of each student so that the learning materials that receive can be remembered because it has a deep meaning in Learners.
\end{abstract}

Keyword: Christian education and Ethics, curriculum 2013.

\section{Pengantar}

Sejatinya Kurikulum 2013 selanjutnya disebutkan sebagai K13 pada jurnal ini, merupakan Kurikulum yang sangat membantu dalam melaksanakan pembelajaran bermakna, terutama pada pembelajaran PAK seperti yang termuat dalam PERMENDIKBUD No. 37 Tahun 2018. K13 bukan saja memuat pada satu aspek pengetahuan atau kognitif dari peserta didik yang mengikuti pembelajaran, namun konsep K13 ini memberikan sentuhan yang sangat berbeda dari kurikulum sebelumnya. Pada K13 disematkan atau membangun pola pikir dari segi spritual atau penghayatan hubungan peserta didik dengan Tuhan sebagai Sang Pencipta, mengasah hubungan sosial atau hubungan yang diharapkan dapat dimiliki oleh peserta didik kepada sesama manusia yang serupa dengan diri peserta didik, membangun pemahaman kognitif atau pengetahuan yang diharapkan dapat dimiliki peserta didik, dan membentuk peserta didik dalam segi keterampilan atau mengasah kemampuan mencipta yang dimiliki peserta didik. Keempat segi ini dikenal sebagai Kompetensi Inti dalam K13.

Terkait dengan segi pengetahuan atau kognitif yang terdapat dalam K13, terutama pada mata pelajaran PAK yang termuat dalam tingkat Sekolah Menengah Atas sesuai yang diatur dalam pelaksanaan proses pembelajaran sebagaimana yang tercantum dalam PERMENDIKBUD No. 37 Tahun 2018 dimana pada peraturan tersebut memuat materi-materi pembelajaran PAK pada tingkat Sekolah Menengah Atas sebagai berikut:

Pembelajaran PAK pada kelas $\mathrm{X}$ memiliki Kompetensi Dasar: Menganalisis ciri-ciri pribadi yang terus bertumbuh menjadi dewasa, Memahami makna nilai-nilai Kristiani: kesetiaan, kasih, dan keadilan dalam kehidupan, Memahami peranan Roh Kudus dalam membaharui kehidupan orang beriman, Menganalisis makna kebersamaan dengan orang lain tanpa kehilangan identitas, Memahami keberadaan Allah sebagai pembaharu kehidupan manusia dan alam.

Pembelajaran PAK pada kelas XI memiliki kompetensi Dasar, yakni: Memahami peranan Allah dalam kehidupan keluarga, Menganalisis pentingnya nilai-nilai Kristiani dalam kehidupan keluarga dan pernikahan, Menganalisis nilai-nilai Kristiani dalam menghadapi gaya hidup masa kini, Memahami peranan keluarga dan sekolah sebagai lembaga pendidikan utama dalam kehidupan masa kini, dan Menilai perkembangan kebudayaan, ilmu pengetahuan, seni dan teknologi dengan mengacu pada Alkitab.

Pada pembelajaran PAK untuk kelas XII memuat Kompetensi Dasar, yakni: Memahami arti demokrasi dan HAM serta mengenali berbagai bentuk pelanggaran demokrasi dan HAM yang merusak kehdiupan dan kesejahteraan manusia, Menganalisis nilai-nilai multikultur, Menganalisis pentingnya keadilan sebagai dasar mewujudkan demokrasi dan HAM pada konteks Global dan lokal mengacu pada Alkitab, dan Menganalisis peran remaja sebagai pembawa damai sejahtera dalam kehidupan sehari-hari selaku murid Kristus.

Pada K13 juga terdapat dua bagian penting yang harus dilaksanakan dalam proses pembelajaran, yakni pembelajaran langsung dan pembelajaran tidak langsung. Pembelajaran langsung ini terkait dengan Kompetensi Inti 3 dan 4 yang tertuang dalam Rencana Pelaksanaan 
IMPLEMENTASI PEMBELAJARAN BERMAKNA PADA MATA PELAJARAN PENDIDIKAN AGAMA KRISTEN DAN BUDI PEKERTI DI SEKOLAH MENENGAH ATAS

Pembelajaran (RPP) sementara pembelajaran tidak langsung terkait dengan Kompetensi Inti 1 dan 2. Untuk kedua hal tersebut harus diperhatikan oleh guru PAK sehingga pembelajaran dapat dirancang dan direncanakan sehingga memberikan makna yang berkesan dalam diri peserta didik.

Dengan adanya konsep yang memberikan peluang untuk materi pembelajaran PAK dapat disampaikan dengan penuh makna yang berkesan pada diri peserta didik, maka perlunya keterampilan dari guru dalam melaksanakan pembelajaran sehingga materi yang diterima oleh peserta didik tidak berlalu begitu saja atau hanya sekedar pemenuhan nilai-nilai yang hendak dicapai oleh peserta didik. Jika pembelajaran tersebut tidak dikemas sedemikian rupa dan memberikan makna yang mendalam maka pembelajaran PAK hanya akan berada pada bagian pelengkap pendidikan dan bukan menjadi pelajaran yang disukai oleh seluruh peserta didik yang mengikuti pelajaran tersebut.

\section{Arti Pembelajaran Bermakna}

Untuk memahami pengertian pembelajaran bermakna menurut David Ausubel ada baiknya memahami terlebih dahulu pengertian dari belajar. Belajar menurut Kamus Besar Bahasa Indonesia adalah berusaha memperoleh kepandaian atau ilmu, berlatih, berubah tingkah laku atau tanggapan yang disebabkan oleh pengalaman. Belajar adalah suatu proses usaha yang dilakukan individu untuk memperoleh suatu perubahan tingkah laku yang baru keseluruhan, sebagian hasil pengalaman individu itu sendiri dalam interaksinya dnegan lingkungan (Moh. Surya 1981:32). Belajar merupakan proses perubahan tingkah laku yang berupa pengetahuan, sikap, dan keterampilan. Perubahan ini bersifat menetap dalam tingkah laku yang terjadi sebagai suatu hasil latihan atau pengalaman. Sementara proses belajar bersifat individual dan kontekstual, artinya proses belajar terjadi dalam diri individu sesuai dengan perkembangannya dan lingkungannya. Pembelajaran adalah sesuatu yang dilakukan oleh siswa, bukan dibuat oleh siswa.

Merujuk kepada pengertian belajar diatas maka kita dapat memahami bahwa pembelajaran merupakan tahap mengubah tingkah laku baik secara keseluruhan maupun sebagian dalam pemahaman peserta didik secara permanen atau menetap dari setiap kegiatan yang dilakukan oleh peserta didik yang dilakukan atau diperoleh secara terus menerus dalam hal ini selama mereka mengikuti pembelajaran di sekolah yang diarahkan terutama kepada mata pelajaran Pendidikan Agama Kristen dan Budi Pekerti.

Sementara itu David Ausubel (1963) seorang ahli psikologi pendidikan menyatakan bahwa bahan pelajaran yang dipelajari harus "bermakna" (meaningfull).

Ausubel menjelaskan bahwa pembelajaran bermakna merupakan suatu proses mengaitkan informasi baru pada konsep-konsep relevan yang terdapat dalam struktur kognitif seseorang. Struktur kognitif ialah fakta-fakta, konsep-konsep dan generalisasi-generalisasi yang telah dipelajari dan diingat siswa (Moh. Suardi, 2012:152).

Pembelajaran secara bermakna merupakan cara mengajarkan materi pembelajaran yang mengutamakan pengertian daripada hafalan (Ragam Model Pembelajaran di sekolah dasar, Tim dosen, 2015:263).

Pembelajaran bermakna terjadi apabila seorang belajar dengan mengasosiasikan fenomena baru kedalam struktur pengetahuan mereka. Dalam proses belajar seseorang mengkonstruksikan apa yang telah ia pelajari dan mengasosiasikan pengalaman, fenomena, dan fakta-fakta baru ke dalam struktur pengetahuan mereka (Rusman dalam Muhammad Fathurohman, 2017:205).

Berdasarkan pengertian tersebut dapat dipahami bahwa pengetahuan atau pemahaman merupakan sesuatu yang harus dimiliki oleh peserta didik terlebih dahulu, kemudian informasi yang diterima dalam proses pembelajaran dikaitkan dengan pengetahuan yang telah dimiliki oleh peserta didik. Keberhasilan pembelajaran bermakna terletak dari keserasian atau berkesinambungan antara informasi yang baru dengan pengetahuan yang telah dimiliki oleh peserta didik.

\section{Kelebihan Dan Kelemahn Pembelajaran Pak Dan Budi Pekerti}

\section{Kelebihan Pembelajaran PAK dan Budi Pekerti}

Pembelajaran PAK dan Budi Pekerti merupakan pembelajaran yang sangat menekankan karakter peserta didik sebagai makhluk ciptaan Tuhan yang mulia sehingga setiap pembelajar memiliki tujuan memproyeksikan akhlak yang mulia sebagaimana Sang Pencipta dalam kehidupan bersama dengan seluruh umat manusia, alam dan binatang yang mendiami seluruh bumi. Karakter ini dipercaya dalam pembelajaran Abad 21 sebagai bagian yang harus dimiliki oleh setiap lulusan, yakni 
nilai-nilai kebangsaan dan kebudayaan lokal yang dapat diterapkan secara global.

Dalam pembelajaran PAK dan Budi Pekerti terutama dalam tingkat Sekolah Menengah Atas memiliki jam pelajaran yang dapat dibilang cukup untuk menyampaikan materi yakni sebanyak 3 jam pelajaran dengan 45 menit setiap jamnya untuk satu minggu.

PAK dan Budi Pekerti juga mendapat pengakuan dari pemerintah yang tercantum dalam rangkaian Kurikulum 2013, dengan demikian adanya landasan hukum yang memayungi mata pelajaran ini dan memiliki kedudukan yang sama pentingnya jika dibandingkan dengan mata pelajaran lainnya.

\section{Kelemahan Pembelajaran PAK}

Kita tidak dapat memungkiri bahwa mata pelajaran Pendidikan Agama Kristen dan Budi Pekerti bukanlah mata pelajaran yang menjadi favorit bagi peserta didik terutama untuk pendidikan Sekolah Menengah Atas. Mata pelajaran PAK dan Budi Pekerti kalah bersaing dengan mata pelajaran lainnya seperti: Matematika, Kimia, Fisika, Biologi, Bahasa Inggris, maupun mata pelajaran yang lainnya. Adanya anggapan bahwa mata pelajaran PAK dan Budi Pekerti hanya sebagai pelengkap dalam struktur kurikulum pendidikan.

Memang mata pelajaran ini mendapat jatah jam pembelajaran cukup banyak yakni 3 jam pelajaran dengan masing-masing jam selama 45 menit setiap minggu. Namun, hal tersebut masih dirasa tidaklah maksimal dalam menerapkan setiap materi pembelajaran sehingga peserta didik dapat mengalami pembelajaran yang bermakna.

Ada banyak hal yang membuat mata pelajaran PAK dan Budi Pekerti ini tidak diminati oleh peserta didik. Penulis mencoba mengamati peserta didik yang mengikuti pelajaran ini dari berbagai sekolah, diantaranya adalah:

a. Kurangnya pendidikan agama yang diterima peserta didik dalam lingkungan keluarga mereka, padahal keluarga merupakan pondasi yang sangat baik untuk menanamkan nilai-nilai agama.

b. Sulitnya mendapatkan guru agama Kristen untuk mengajarkan PAK dan Budi Pekerti, sehingga peserta didik mendapatkan nilai agamanya dari lembaga lain seperti gereja. Hal ini merupakan sesuatu yang keliru dalam dunia pendidikan dan harus diperbaiki jika pendidikan agama di Indonesia menjadi pendidikan yang maju.

c. Keterampilan guru mata pelajaran PAK dan Budi Pekerti yang sangat minim untuk menguasai materi pelajaran yang akan disampaikan kepada peserta didik, minimnya keterampilan mengajar sehingga materi yang disampaikan menjadi monoton atau tidak menyenangkan dalam pemikiran peserta didik.

Dengan demikian kita dapat memahami bahwa banyak sekali hal yang harus dibenahi dalam menerapkan pembelajaran bermakna. Melihat dari pengertian yang dikemukakan oleh David Ausubel bahwa pembelajaran bermakna itu membutuhkan pemahaman atau konsep-konsep yang dimiliki oleh peserta didik sebelum mendapatkan informasi yang baru. Oleh karena itu penulis menitikberatkan pada pemahaman yang harus dimiliki oleh setiap peserta didik yang dimana seharusnya sudah dimiliki paling tidak dalam pendidikan agama di dalam lingkungan keluarga.

\section{Keterampilan Guru Dalam Menyampaikan Materi Yang Bermakna Pada Pembelajaran Pak}

Penulis melihat bahwa adanya makna yang harus dimiliki terlebih dahulu dalam diri guru terkait dengan materi pembelajaran PAK dan Budi Pekerti. Guru harus memiliki kesan yang dalam terkait materi yang akan disampaikan kepada peserta didik, dengan demikian guru memiliki antusias atau semangat untuk menyampaikan materi pembelajaran kepada peserta didiknya.

Pembelajaran bermakna ini juga ditentukan oleh bakat dan minat peserta didik. Ada baiknya guru PAK dan Budi Pekerti dapat memahami karakteristik setiap peserta didik yang diajar, sehingga setelah mengetahui setiap karakteristik peserta didik diharpkan guru memiliki kemampuan untuk merancang pembelajaran yang menarik agar peserta didik dapat mengimplementasikan materi sesuai dengan konteks kehidupan yang dialami secara nyata.

Menurut teori belajar bermakna, guru tetap berfungsi sentral sebatas membantu mengkoordinasikan pengalaman-pengalaman yang hendak diterima oleh peserta didik, namun tetap dengan koridor pembelajaran yang bermakna (Moh. Suardi, 2012:160).

Dengan demikian proses pembelajaran memerlukan seorang manager yang baik dalam melaksakan kegiatan pembelajaran, dimana guru harus mengkoordinir setiap detai-detai, sikap-sikap, informasi-informasi yang disampaikan sehingga pengetahuan yang baru tersebut mampu diterima oleh peserta didik dengan baik dan dipahami secara konteks kehidupannya. 
IMPLEMENTASI PEMBELAJARAN BERMAKNA PADA MATA PELAJARAN PENDIDIKAN AGAMA KRISTEN DAN BUDI PEKERTI DI SEKOLAH MENENGAH ATAS

Guru PAK dan Budi Pekerti juga dituntut untuk menjadi seorang pengembang program pembelajaran dengan berusaha mengetahui dan menggali konsep yang telah dimiliki oleh peserta didik yang kemudian membantu mereka memadukan secara harmonis setiap pengetahuan yang telah dimiliki dengan pengetahuan baru yang dipelajari sehingga semuanya akan bermakna.

Tugas dari guru yang tidak dapat dilepaskan dalam pembelajaran bermakna adalah bagaimana guru mampu menjadi evaluator pembelajaran (Dina Gasong, 2018:7). Dalam setiap kegiatan pembelajaran yang telah dilakukan oleh guru, hendaknya guru memperhatikan bagaimana perencanaan yang telah dipersiapkan, koordinasi kelas selama pembelajaran berlangsung dan kemudian mengevaluasi secara keseluruhan sampai mendapatkan sebuah kesimpulan apakah materi pelajaran yang disampaikan bermakna dalam diri peserta didik atau tidak. Guru mampu menemukan solusi dari setiap kendala yang dihadapi selama proses pembelajaran berlangsung, sehingga pada pertemuan berikutnya materi yang disampaikan dapat memiliki makna yang jauh lebih mendalam bagi peserta didik. Jika pada pertemuan sebelumnya gagal memberikan makna dalam diri peserta didik maka guru harus bergegas membenahi kesalahan yang telah dilakukan.

\section{Implementasi Pelaksanaan Pembelajaran Bermakna Pada Materi Pembelajaran Pak}

Dapat dipahami bahwa dalam pembelajaran bermakna setiap aturan-aturan, detail-detai, sifatsifat dalam materi tidaklah diberikan secara langsung ataupun utuh sehingga peserta didik hanya menerima informasi, jika demikian maka pembelajaran bermakna tidaklah tercapai. Justru sebaiknya setiap hal yang terkait dalam materi pelajaran ditemukan secara induktif oleh peserta didik yang kemudian dibuktikan secara deduktif.

Ketika peserta didik mempelajari PAK dan Budi Pekerti mulai dari proses terbentuknya suatu konsep kemudian berlatih menerapkan dan memanipulasi konsep-konsep tersebut kedalam situasi atau konteks yang baru maka pembelajaran bermakna dapat tercapai. Dengan demikian peserta didik terhidar dari verbalisme karena mereka telah menemukan secara induktif mengenai pengetahuan atau informasi yang telah disampaikan oleh guru.

Karena pembelajaran bermakna menuntut peserta didik menemukan makna yang diperoleh dari informasi baru yang disampaikan oleh guru, maka peserta didik dituntut untuk memiliki kemampuan dalam mencari informasi dan mengalami sendiri sehingga mampu menjawab tantangan dimasa depan dan tidak hanya sekedar memahami sebuah konsep pengetahuan melalui pengalaman nyata.

Pembelajaran yang menyenangkan, kreatif, dan inovatif dipercaya akan membuat peserta didik memiliki sikap aktif dalam mengikuti setiap proses pembelajaran yang dalam hal ini tentang mata pelajaran PAK dan Budi Pekerti.

Pembelajaran yang disampaikan oleh guru bukanlah sekedar pemindahan informasi secara mutlah atau utuh. Pembelajaran bermakna pada mata pelajaran PAK dan Budi Pekerti harus dipahami bahwa pembelajaran bukanlah sekedar menghafal konsep-konsep atau fakta-fakta, tetapi merupakan kegiatan menghubungkan konsep-konsep untuk menghasilkan pemahaman yang utuh sehingga konsep yang dipelajari akan dipahami secara baik dan tidak mudah untuk dilupakan.

\section{Ucapan Terima Kasih}

Penulis menyampaikan terima kasih bagi pihak redaktur yang memberikan masukan begitu baik sehingga tulisan ini dapat disajikan dalam jurnal ini. Penulis Juga ingin menyampaikan terima kasih untuk setiap bantuan dan dukungan dalam hal apapun dari berbagai pihak untuk membantu dalam penulisan ini.

\section{Pustaka Acuan}

Dina Gasong. Belajar dan Pembelajaran. Yogyakarta: Deepublish. 2018.

Husamah. Belajar dan Pembelajaran. Malang: UMMpress. 2016

Kamus Besar Bahasa Indonesia

Moh. Suardi. Belajar dan Pembelajaran. Yogyakarta: Deepublish. 2012.

Muhammad Fathurrohman. Belajar dan pembelajaran. Yogyakarta: Garudhawaca. 2017.

Tim Dosen. Ragam Model pembelajaran di Sekolah Dasar. Sumedang: UPI SUMEDANG. 2017. 